Прегледни чланак

András Téglási, Ph.D., Associate Professor

National University of Public Service, Budapest

Faculty of Science of Public Governance and Administration

Teglasi.Andras@uni-nke.hu

\title{
THE CASE LAW OF THE CONSTITUTIONAL COURT REGARDING THE CONSTITUTIONALITY OF THE PARLIAMENTARY ELECTORAL SYSTEM OF HUNGARY BETWEEN 2012 AND 2017
}

\begin{abstract}
Hungary's new constitution (also known as the Basic Law or Fundamental Law) reformed the rules governing the election of members of parliament. The Hungarian parliament further reshaped these rules with two subsequent pieces of legislation: the Act CCIII of 2011 on the election of members of parliament, and the Act XXXVI of 2013 on Electoral Procedure. The material and procedural rules for the elections have introduced new features into the electoral system which many have criticized for constitutional considerations. This paper systematically introduces the Hungarian Constitutional Court's decisions on legal norms for parliamentary elections as they have developed since the adoption of the act on electoral procedures.
\end{abstract}

Keywords: Hungary, constitutional courts, electoral procedures, electoral systems.

\section{INTRODUCTION}

When the Parliament adopted the new constitution of Hungary (also called the Basic Law or the Fundamental Law), in 2011, it also reformed the rules governing the election of members of parliament through two major pieces of legislation: first, the Act CCIII of 2011 on the election of members of parliament (hereinafter also abbreviated as: „Vjt.”), ${ }^{2}$ and then the Act XXXVI of 2013 on Electoral Procedure

\footnotetext{
1 , Supported BY the ÚNKP-17-4-III-NKE-3 New National Excellence Program of the Ministry of Human Capacities"

2 Ákos Cserny, Iván Halász Iván, András Téglási András: A képviseleti demokrácia érvényesülése. A választójog és a választásokkal kapcsolatos szabályozás. In: Ákos Cserny (ed.): Alkotmányjog. Nemzeti Közszolgálati Egyetem, Budapest 2014. 136.
} 
(hereinafter also abbreviated as: Ve.). Many criticized the new material and procedural rules for elections for being unconstitutional. ${ }^{3}$

The Constitutional Court of Hungary (hereinafter also abbreviated as: „CC”) has been examining changes to the electoral law since the Parliament first adopted the act on electoral procedures. This article systematically introduces the CC's decisions on legal norms for parliamentary elections in the period before Hungary's 2018 parliamentary elections. ${ }^{4}$

\section{DECISION 1/2013. (I. 7.) AB - PRELIMINARY REVIEW SUBMITTED BY THE PRESIDENT OF THE REPUBLIC}

\subsection{The case}

The Parliament adopted the Act on the Electoral Procedure (hereinafter: "Act") at its session of 26 November 2012. The Speaker of the Parliament sent the Act to the President of the Republic for signing and ordering its promulgation. The President of the Republic turned, within the period specified for this purpose (i.e. 5 days $^{5}$ )

${ }^{3}$ See the major changes and their criticisms up to the 2014 elections: Ákos Cserny, Téglási András: "Certain Elements of the Transformed Hungarian Electoral System in the Light of the Experience of the 2014 Elections." Osteuropa-Recht 3/2015 335-362.; Csaba Cservák: Választási rendszerek - és az új magyar megoldás (Electoral systems - the new Hungarian solution), in: Ádám Rixer (ed.): Állam és közösség: Válogatott közjogi tanulmányok Magyarország Alaptörvénye tiszteletére. Károli Gáspár Református Egyetem, Állam- és Jogtudományi Kar, Budapest 2012, 289-290.; Csaba Cservák: Unconventional Electoral Systems: And The Hungarian Solution. International Journal Of Humanities And Social Science Invention 2/2017 21-29.; Csaba Cservák: A Historical Overview of the Emergence of Certain Electoral Systems. Journal On European History Of Law 2/2017. 50-57.; András Patyi, Zsuzsanna Fejes: „Xiongyali yihui xuanjufa biange de fenxi yu zhanwang." = Some Changes in Hungarian Parliamentary Electoral Law - JOURNAL OF EAST CHINA UNIVERSITY OF POLITICAL SCIENCE AND LAW / HUADONG ZHENGFA DAXUE XUEBAO 2017:(6) pp. 116-134. (2017). Concerning the changes in referendum law see: András Patyi: EL REGLAMENTO JURÍDICO Y LA JURISPRUDENCIA DE LOS REFERÉNDUMS NACIONALES Y LOCALES EN HUNGRÍA DESDE LA TRANSICIÓN POLÍTICA DE 1989 HASTA LA ACTUALIDAD. In: Gerardo Romero Altamirano, Gema N Morales Martínez (ed.): Mecanismos de Participación Ciudadana. Una Experiencia Global. Ciudad de México: Tirant lo Blanch, 2017. pp. 181-211.

${ }^{4}$ This paper only examines the period 2012-2017, analyzing only judgments that have been subject to norm control and deals only with parliamentary election rules. Thus, we do not mention either the orders of the $\mathrm{CC}$ that do not carry out substantive investigations or the $\mathrm{CC}$ decisions on electoral and electoral law based on constitutional complaints. Due to the scope of the topic of this paper, we do not discuss the 26/2014. (VII.23) AB and Decision 3002/2015. (I.12.) AB as they did not examine rules related to the election of members of the parliamentary assembly, but rather the rules that govern the election of the members of the Budapest Assembly.

${ }^{5}$ According to Article 6 para. (3) of the Basic Law: „The President of the Republic shall sign the Act within five days of receiving it and order its publication." 
to the $\mathrm{CC}$ on the basis of Article 6 para. (4) of the Basic Law. ${ }^{6}$ The President of the Republic initiated the preliminary review of many sections of the Act not yet promulgated with regard to their compatibility with the Basic Law.

\subsection{Establishments of the $\mathrm{CC}$ - central registry to vote}

The Act regulates the central registry of names as the fundament of exercising the right to vote. There are several provisions in the Act requiring citizens to request registration in the central registry as a precondition of exercising their right to vote. Thus the Act sets an extra-statutory condition for exercising the right to vote granted as a fundamental right in Article XXIII of the Basic Law.

In reviewing the compatibility of the Act with the Basic Law, the CC took due account of foreign examples of legally-mandated voter registration systems. In this context, prior to the review of the provisions on the merits, the CC held it important to establish that the constitutionality of a specific legal institution in any state depends on how it fits into the state's constitution, its legal system, and its historical and political context. Therefore, although the CC acknowledges that taking foreign experiences into account may help to evaluate certain regulatory solutions, it does not consider foreign examples in themselves as determining factors with regard to the review of constitutionality (compliance with the Basic Law).

First of all, the $\mathrm{CC}$ had to decide on the aplicability of its previous case law, passed before the Basic Law, to the present case. The right to vote was enshrined as a fundamental right in Article 70 of the previous Constitution, similarly acknowledging the right to vote of those who have suffrage under Article XXIII of the Basic Law. The contents of Article 70 of the Constitution were similar to that of the Basic Law also with regard to restricting the right to vote; neither did the Constitution contain any requirement about linking the right to vote to submitting a request for registration in the central electoral register. That said neither constitutional text links the right to vote with submitting a request for registration to the central electoral register. At the same time, with respect to Hungarian citizens, the Basic Law does not prescribe a Hungarian domicile as a precondition of the right to vote, nonetheless it grants the right to vote to a group of Hungarian citizens who did not have suffrage before, i.e. citizens living outside Hungary's borders but do not have an address in Hungary. With regard to the majority of constituents, however, the contents of the regulations on the right to vote is the same both in Article XXIII of the Basic Law and in Article 70 of the old constitution. Therefore the CC's interpretation of the law as contained in its previous decisions

${ }^{6}$ According to Article 6 para. (4) of the Basic Law: „If the President of the Republic considers an Act or any of its provisions to be contrary to the Fundamental Law, and no examination pursuant to paragraph (2) has been conducted, he or she shall send the Act to the CC for an examination of its conformity with the Fundamental Law." 
is to be followed in the course of reviewing the present case, too. This means that the Court decided its previous case law would apply to considering new electoral legislation.

The CC established that voting citizens have an influence on the composition of the supreme body of state power and popular representation by exercising their active voting rights every four years. Therefore, "any restriction on the equality or generality of this right can only be accepted as constitutional on the basis of a significant reason of principle." ${ }^{7}$ Later in the decision, the Courts states: "A stable, lawful and predictably operating election system is an indispensable precondition of a political system based on the principle of democracy." Articulating the electors' will through elections 'constitutes, legalizes and legitimizes' the representative bodies exercising public power."

Consequently, the right to vote is a fundamental right that must be enforced through state regulation, i.e. the conditions of exercising it shall be granted by the State. In this respect the right to vote is a fundamental right having a twofold function; on the side of the electors it embodies participation in public affairs and an indirect form of making decisions through public authority, and from the state's vantage point it acts as a tool for establishing and legitimizing representative government. The subjective side of the right to vote ${ }^{9}$ is suffrage, as the fundamental political right of the citizen. Suffrage is a fundamental right acknowledged in the Basic Law, guaranteeing the enforcement of the principle of popular sovereignty. The subjective side of suffrage basically contains the freedom of the electors to decide whether they exercise their right to vote or not, and for whom they cast their votes.

The State must be active in facilitating citizens' exercise of their right to vote. The right to vote has a side of institutional protection where the State must create and enforce the regulations allowing and facilitating the exercising the right to vote. It follows that the state may not hinder the exercise of the right to vote, in a manner restricting participation at the elections contrary to the Basic Law. Thus the enforceability of the right to vote as a subjective right depends on the precondition of the State guaranteeing its exercise and providing adequate guarantees to it.

${ }^{7}$ Decision 6/1991. (II. 28.) AB, ABH 1991, 19, 20.

${ }^{8}$ Decision 39/2002. (IX. 25.) AB, ABH 2002, 273, 279.

9 The Hungarian CC differentiates the „subjective side” of a fundamental right and its „institutional aspects”. The subjective side refers to a person's individual subjective, justiciable right, as one aspect of a fundamental right, which is not necessarily of the same extent as its objective aspects (i.e. the institutional protection of a fundamental right). See this differentiation regarding the right to life in Decision 64/1991 of the Hungarian CC: László Sólyom, Georg Brunner, Stephen G. Breyer: Constitutional Judiciary in a New Democracy: The Hungarian CC. The University of Michigan, 2000. p. 186.; regarding the right to property: László Sólyom, Georg Brunner, Stephen G. Breyer: Constitutional Judiciary in a New Democracy: The Hungarian CC. The University of Michigan, 2000. p. 182-183. 
However, the Court's decision also included the important following statement: „The Parliament has a wide scale of discretion in establishing the system of election and the rules of procedure of the election. The legislator is free to define the constituency systems and the rules pertaining to the nomination of candidates, voting and the obtainment of mandates. The Parliament may exercise this freedom of discretion in establishing the rules of election only within the constitutional limits, and it is required to adopt rules that do not violate the provisions of the Constitution and do not unconstitutionally restrict any fundamental right regulated in the Constitution."10

It follows from the practice of the $\mathrm{CC}$ that the right to vote plays an important role in enforcing an effectively functioning democracy. General and equal suffrage must be fully secured in order to guarantee the unquestionable legitimacy of the elected (legislative) power and the decisions (Acts) adopted by it. In other words, although the State enjoys a wide scale of discretion regarding the adoption of concrete regulations, the conditions of exercising the right to vote may not hinder the free expression of the people's will; they also may not hamper the freedom of determination manifested in the right to vote. A single election rule or a specific legal institution of election law can rarely be regarded as one restricting the freedom of elections. The totality of the election rules should meet the requirement of facilitating - above all - the free expression of the electors' preferences.

Therefore, in the opinion of the $\mathrm{CC}$, the constitutional requirement about the closedness of the causes of exclusion from the right to vote (that said the conditions of the electoral rights constitute a closed system, therefore exclusion from the right to vote is possible only in the cases expressly mentioned in the Constitution) is to be followed both on the basis of the Basic Law and on the former practice of the CC. With this statement the CC's decided whether or not certain rules violate the right to vote depends on whether they conflict with the Fundamental Law or the precedent set by the $\mathrm{CC}$. At the same time, the $\mathrm{CC}$ points out that the concrete method and the detailed regulations on exercising the right to vote are to be regulated in an Act of Parliament, on the basis of Article XXIII of the Basic Law and Article I para. (3), which concerns restrictions of fundamental rights.

As mentioned earlier, the Act introduces an active method of election registration, making the exercising one's right to vote conditional upon filing a request for registration in the electoral register, either through submission to a notary, by mail in a specific scope, or through the electronic gateway. However, in the case of Hungarian citizens having a domicile in Hungary - as explained below - there is no constitutionally justifiable reason for excluding from the exercising of the right to vote those who have not asked for registration in the electoral register. On the basis of the freedom of the right to vote, the $\mathrm{CC}$ established that Section 82 para. (3) of the Act was contrary to Article XXIII of the Basic Law.

${ }^{10}$ ABH 1996, 509, 513. 
Ever since the free parliamentary elections in 1990 electors living in Hungary have been able to exercise their right to vote without an obligation of registration. This manner of exercising the right to vote has become a regular feature of the election procedure. However, it is not possible to decrease without justification the partial rights developed in the area of exercising the right to vote, and they could only be restricted in compliance with the Basic Law, in line with Article I para. (3). The State has to grant to all persons, having a right to vote, the enforcement of the freedom of determination manifested in the right to vote, as a part of the State's obligation of institutional protection.

The CC established the following in its reasoning: it is a constitutional requirement following from Article XXIII of the Basic Law that the rules of the electoral procedure should facilitate the exercising of the right to vote. As a related constitutional requirement, the necessary data of all persons, having a right to vote according to the registry maintained by the State, shall be entered into the central registry of names, thus granting the equal exercising of the right to vote for all persons having suffrage.

Section 88 para. (1) of the Act is considered as a disproportionate restriction of the right granted in Article XXIII of the Basic Law, as it requires the submission of the request at the notary competent according to the address of the elector.

Thus, according to the Act, those electors who have both a registered domicile and a registered place of residence, they can only file the request with the notary for their given jurisdiction. The court ruled that this represents a disproportionate burden for electors as a precondition of exercising their right to vote. Accordingly, the CC established that Section 88 para. (1) of the Act is contrary to the Basic Law.

In the present case, the $\mathrm{CC}$ established that there is no justification to exclude electors living in Hungary from registration because they do not have an address, as opposed to those who do. Section 91 para. (2) of the Act itself contains offers a basis for personal registration if someone's personal identity can be verified beyond doubt, but other data found in their request are uncertain. Taking this into account, it is an unjustified restriction not to grant the possibility of personal registration, similarly to Section 91 para. (2) of the Act, for the electors living in Hungary and not having an address. Accordingly the CC established that Section 92 of the Act is an instance of negative discrimination because it excludes electors living in Hungary without addresses from requesting registration in the central registry.. In this respect, Section 92 para. (3) of the Act is contrary to Article XV para. (2) of the Basic Law in the context of Article XXIII. At the same time, the $\mathrm{CC}$ established that no negative discrimination can be established on the basis of Article XV para. (2) of the Basic Law due to providing the possibility of registration in mail by Section 92 of the Act, with regard to the affected persons, i.e. the electors living in Hungary without having an address. 


\subsection{Establishments of the $\mathrm{CC}$ - political advertisement}

According to Section 151 para. (1) of the Act, during the campaign period only public service media is allowed to disseminate political advertisements. The provision prohibits this type of political communication in any other media, including private television and radio stations. This prohibition seems to restrict the very forms of media that are likely to reach most of the population. Therefore, the prohibition significantly restricts political expression during the course of the election campaign.

CCIn the course of examining previous rules on political advertising in the media, the $\mathrm{CC}$ has stated the following:

The media has a particularly important role in influencing the opinion of the public, and it is of prominent importance that in the period of election campaigns the right to the freedom of expression and the right to have information on data of public interest should be enforced in the framework of broadcasting. ${ }^{11}$

The freedom of expression by political parties is particularly important because it is the constitutional duty of the parties to contribute to forming and manifesting the people's will. The CC explained when it interpreted the similar provision of the former Constitution that ,the parties' role played in forming the people's will includes the communication and the promotion of this activity by way of public advertisements."12

As recalled by the $\mathrm{CC}$, the the media's considerable influence may justify using legislation to impose certain extra obligations - with due respect to the equal opportunities of the competing political parties - even if the campaign activities are not restricted in general. However, with regard to the aim of allowing the free formation and the expression of the voters' will, it is gravely disproportionate to ban political advertisements on the wide scale as specified in Section 151 para. (1) of the Act, especially when the legislator has significantly eliminated the restrictions applicable to the campaign activities. With regard to the diverse relations between political advertisements, the freedom of expression and the freedom of the press, such advertisements cannot be constitutionally prohibited, as found in the Act under review, even outside the scope of the public service media.

However the CC established that Section 151 para. (1) of the Act does not serve the purpose of providing balanced information-indeed, its result is to the contrary. The provision's prohibition on private media political advertisements is not only likely to influence the voters' will, but also inform them, with regard to

\footnotetext{
${ }^{11}$ Decision 60/2003. (XI. 26.) AB, ABH 2003, 620, 621.

${ }^{12}$ Decision 44/2008. (IV. 17.) AB, ABH 2008, 459, 463.
} 
the media type that can reach the widest scope of electors. Accordingly, the CC established that the Act's prohibition was contrary to the Basic Law.

The President of the Republic challenged in his petition in particular Section 151 para. (3) of the Act as well. According to this provision, in the 48 hours leading up to an election, the public service media is likewise barred from disseminating political advertisements. The CC established in the respect of Section 151 para. (3) of the Act, that it was not a disproportionate restriction in itself if the broadcasting of political advertisements was fully prohibited in the media services within 48 hours prior to the elections. Such a restriction can be justified with the aim of avoiding influencing the voters' expression of their will. Nevertheless, CCBasic LawBasic Lawbecause of the way the provision on private media, discussed above, and Section 151 para. (3) might interact to completely limit political advertisement immediately ahead of elections, the Court ruled Section 151 para. (3) unconstitutional.

The CC then examined Section 152 para. (5) of the Act, prohibiting cinemas from showing political advertisements during the campaign period. The CC established that in the case of the cinemas there are not any special reasons that might justify the particular restrictions applicable in the case of media services. Therefore, in this case, - taking into account in particular that the legislator abolishes the general restriction on campaign activities - there is no constitutional justification for the ban on political advertisements. Thus Section 152 para. (5) of the Act is unconstitutional.

\subsection{Establishments of the $\mathrm{CC}$ - disclosing of opinion-poll results}

The Act also restricts the disclosure of opinion-poll results on the grounds that this restriction is necessary for the undisturbed implementation of elections. However, it is a legitimate constitutional question whether the given aim - to secure the undisturbed expression of the voters' will - could only be reached by imposing such a restriction on the fundamental freedom of expression and the freedom of the press.

The $\mathrm{CC}$ holds that restricting the freedom of expression, the freedom of the press and the freedom of information in the manner specified in Section 8 para. (1) of the Act XXXVI of 2013 on Electoral Procedure is unconstitutional, even if one admits that the opinion-poll results have an influence on the voters' behaviour. Although the undisturbed implementation of the elections is a legitimate, constitutionally acceptable, aim for the restriction, the prohibition of 8 to 6 days is disproportionate with this objective. The Constitution protects the expression of the independently-formed opinion of the public built upon as broad information as possible. 
The CC established that the restriction of six days contained in Section 154 para. (1) of the Act restricts the freedom of expression and the freedom of the press not unnecessarily but disproportionately, thus violating Article I para. (3) and Article IX of the Basic Law.

\subsection{Five dissenting opinions and one concurring reasoning}

A concurring reasoning by Péter Kovács, Judge of the CC, has been attached to the decision. He provides a more detailed analysis of the case-law of the ECHR. After completing his mandate, he was elected to be Judge of the International Criminal Court.

Dissenting opinions by István Balsai, Egon Dienes-Oehm, Barnabás Lenkovics, Béla Pokol, and by Mária Szívós, all Judges of the CC, have been attached to the decision.

\section{CONSTITUTIONAL COURT DECISION NO. 3141/2014. (V. 9.) AB - THE „WINNER-COMPENSATION”}

In this decision the $\mathrm{CC}$ examined the provisions of the Act on the Elections of Parliament Members concerning the winner compensation and declared that they do not violate the constitutional requirements of the equality of the right to vote.

\subsection{The antecedents of the case}

The constitutional complaint was submitted by an opposition political party against $\S 15$ (1) (b) of Act CCIII of 2011 on the elections of members of parliament.

According to the text of the challenged provisons:

„§ 15 (1) Surplus votes in any single-member constituency shall include:

(...) b) the number of votes remaining after deducting the number of votes for the runner-up candidate plus one from the number of votes for the candidate who won the mandate."

The applicants contended that the provision of the concerned Act is contrary to the requirement of the equality of right to vote. In their view, the mandates that may be won from the party list by the surplus votes are meant to be a compensation in connection with the votes cast in the individual constituency. However, the compensation of the winner without any constitutional reason restricts the requirement of the equal weight of votes. 


\subsection{Findings of the $\mathrm{CC}$ - equal suffrage}

The CC pointed out to the fact that because the Vjt. regulates a mixed electoral system in Hungary, it combines some of the characteristic elements of the majoritarian and proportional electoral system. ${ }^{13}$

In accordance with its case law, the $\mathrm{CC}$ pointed out that the Basic Law does not contain detailed provisions about the electoral system itself, prescribing only some electoral principles. Therefore, the Parliament has wide discretion to decide on the electoral system, the rules of the electoral procedure and the order of the distribution of mandates. However, this hardly means that the requirements of the Basic Law should not be taken into account.

The CC also pointed out that the principle of equality of right to vote as stipulated in Article 2 para (1) of the Basic Law, ${ }^{14}$ is not a fundamental right but a constitutional principle, a guarantee governed by the Basic Law. Therefore, its violation shall not be judged according to the necessity and proportionality test set out in Article I (3) of the Basic Law. ${ }^{15}$

When examining the equality of the right to vote, the CC looked through its previous case law. The equality of the right to vote as a constitutional principle necessitates the equal value of individual votes (and thus the exclusion of plural voting rights) as an absolute requirement, and the relative equal weight of votes if possible. The equality of the right to vote does not mean that expressed political wills prevail equally without any derogation.

The CC cited its previous decision no. 22/2005. (VI.17.) AB, which established the following: the equal value of votes means that all voting citizens have the

${ }^{13}$ The parliament features 106 district mandates and 93 party-list mandates. Voters cast two votes in national elections: one for representatives in the voters' individual constituency, and one for party lists. Individual constituencies are awarded on a winner-take-all basis. The votes are aggregated across the country and additional parliamentary seats are awarded to parties based on these results, above and beyond the seats won in the individual districts. The unique feature of the election system is the winner compensation. Previously parties were compensated by gaining extra votes in their party list totals, which occurs when their candidates win a lower share of individual constituencies than the popular vote would predict. Under the new election system, the party winning an individual constituency will be awarded not only that particular mandate, but also extra points in the party-list calculations when it wins by more votes than needed.

${ }^{14}$ According to Art. 2 para (1) of the Fundamental Law of Hungary: „Members of Parliament shall be elected by direct and secret ballot by citizens eligible to vote, on the basis of universal and equal suffrage, in elections which guarantee free expression of voters' will, in a manner laid down in a cardinal Act."

${ }^{15}$ According to Art. I para (3) of the Fundamental Law of Hungary: „A fundamental right may only be restricted in order to allow the exercise of another fundamental right or to protect a constitutional value, to the extent that is absolutely necessary, proportionately to the objective pursued, and respecting the essential content of such fundamental right." 
same number of votes, and, in counting the votes, all votes have the same value. ${ }^{16}$ However, from the point of view of equality in terms of content, the actual number of votes it takes to secure a mandate in the course of the parliamentary elections is irrelevant. In majority-based systems, inevitably, different numbers of votes result in a mandate even in constituencies of the same size, as the number of and the level of support for the competing candidates (parties) may differ in the various constituencies, and there may be different numbers of voting citizens actually participating in the voting. As a consequence, the requirement that the votes be "preferably of equal weight" and "of almost the same weight" cannot be applied to the actual votes - for single-member candidates and regional lists - cast by voting citizens and to their interrelations. Differences caused by the rate of participation at the elections and by the activity of voting citizens, as well as the actual distribution of votes do not influence the enforcement of the principle of equal voting rights resulting from the Constitution. In sum, he practice of the CC does not require the ,effective equality” of the right to vote.

In the view of the $\mathrm{CC}$, the application of the majoriarian, proportional or the mixed electoral system does not mean the violation of the equal weight of the votes. The challenged provision does not obstruct the right of the petitioners to vote and stand as candidates in parliamentary elections. Also, the provision does not undermine the equal chances of the candidates prior to the elections. According to the $\mathrm{CC}$, the actual system does not support the organisation whose candidate won the relative majority during the elections. Instead, it supports the organisation that nominated the winner candidate in the individual constituency. This is not necessarily the same organisation with the relative majority regarding the final result of the elections. Furthermore, only a significant number of extra votes cast for the winner candidate results in a mandate.

\subsection{Findings of the $\mathrm{CC}-$,Winner Compensation”}

The CC established that the provisions of the Act on the Elections of Parliament Members concerning the winner compensation do not violate the constitutional requirements of the equality of the right to vote.

\subsection{Three dissenting opinions and a concurring reasoning}

Judge Béla Pokol judge attached concurring opinion and Judges András Bragyova, László Kiss and Miklós Lévay judges attached dissenting opinion to the decision.

\footnotetext{
${ }^{16}$ See the translation of this decision in English at the official website of the CC of Hungary (https://hunconcourt.hu/uploads/sites/3/2017/11/en_0022_2005.pdf)
} 
3. CONSTITUTIONAL COURT DECISIONS NO. 3001/2015. (I. 12.) AB AND 3176/2015. (IX. 23.) AB - REPAYMENT OF SUBSIDIES OF MP CANDIDATES

\subsection{The antecedents of the case}

A Judge of the Administrative and Labor Court of Kecskemét and the Judge of the Municipal Administrative and Labor Court presented a judicial initiative with the suspension of the case pending before them, requesting the annullment of $\S 8$ (4) a) the Act LXXXVII of 2013 on the transparency of the campaign expenses of the election of MPs. According to the challenged legal provision: „8. § (4) If the candidate (a) does not acquire at least $2 \%$ of the valid votes cast in the constituency, [...] he shall repay the subsidy under $\S 1$ to the Treasury."

\subsection{The statements of the $\mathrm{CC}$ - necessity and proportionality}

One of the three panels of the CC ruled that it is clear from the text of the Act that its subject is not nomination of candidates but the equal distribution of campaign financing for those who have already been nominated. It follows that each candidate decides whether or not he or she is eligible according to the law and whether he or she is using state aid or waiving the subsidy for the benefit of his or her party. The Act therefore does not exclude that the candidate himself finances his campaign on his own behalf. As a result, the application of the provision under consideration, that is, the enforcement of the repayment obligation discussed above may not arise. In accordance with the requirement of Article I (3) of the Basic Law, ${ }^{17}$ the CC has examined whether the potential repayment obligation of the campaign finance restricts passive voting rights (i.e. the right to be elected) to the extent that is absolutely necessary and proportionately to the objective pursued.

In this case, the $\mathrm{CC}$ considered the regulation of campaign financing to be part of the way the state facilitates the exercise of a fundamental right and the realization of the rights of those concerned, in this case: by candidates. In this context, the CC also emphasized that Article 8 para. (4) (a) of the Act does not regulate nomination (becoming a candidate), but imposes an obligation of a financial nature for those who have already been nominated. This shall be applied to the candidate if he or she does not receive at least $2 \%$ of the valid votes cast. The constitutional concern is that this type of repayment obligation might have a

\footnotetext{
${ }^{17}$ Art. I para (3) of the Fundamental Law reads as follows: „The rules relating to fundamental rights and obligations shall be laid down in Acts. A fundamental right may only be restricted in order to allow the exercise of another fundamental right or to protect a constitutional value, to the extent that is absolutely necessary, proportionately to the objective pursued, and respecting the essential content of such fundamental right."
} 
deterrent effect on the specific exercise of passive voting rights, that is to say, it might unconstitutionally limit a fundamental right.

The CC held that the protection of the fairness of the election and the function of electoral process in ensuring democratic legitimacy forms a constitutional value that can limit the unlitimed realization of passive voting rights. Nomination of candidates could become unlimited, furthermore businesslike, if there were no austerity conditions associated with the financial support of candidates, the enforcement of which is indispensable for public finances. Each candidate can predict if he or she does not win the support of a specific part of the voters, he or she is likely to lose funding as a result. The state wants to achieve conditions that provide candidates with an equal chance to persuade voters. If a candidate cannot take advantage of this opportunity, he or she loses the support. Still, this candidate could have exercised his or her passive voting right during the electoral process. Therefore, the $\mathrm{CC}$ has established the necessity of the regulation under Article I (3) of the Basic Law.

With respect to the proportionality of the restriction, the $\mathrm{CC}$ has taken into account the following: the imposition of an excessively high amount of electoral support on the non-repayment of the aid would, on the one hand, empty out the campaign financing and, secondly, it would indeed be capable of unduly reducing the inclination to become eligible (i.e. candidates' inclination to run for office). The $2 \%$ subsidy threshold under the legislation under review can most likely be reached by winning less than a thousand voters. According to 6 . $\S$ of Vjt., a nomination of at least five hundred voters is required for becoming a candidate. That is, the number of the funding threshold is higher, but it is not likely to be more than double that of the subsidy threshold. Undoubtedly, in case of the increased number of voters, this threshold also increases, but it cannot be more than two thousand even with full participation (i.e. 100\% turnout). As a result of the investigation, the $\mathrm{CC}$ found that the regulations in question were in conformity with the requirement of Article I (3) of the Basic Law in respect of passive voting rights, and therefore remain within the limits of the proportionate purpose to be achieved. The Judicial Initiative was therefore rejected by Constitutonal Court in Decision no. 3001/2015. (I.12.) AB.

\subsection{The statements of the $\mathrm{CC}$ - the right to property and equality of opportunity}

The CC also produced substantive findings about the other judicial initiative. In relation to property rights, the $\mathrm{CC}$ pointed out that campaign financing involves a complex set of financial factors. One of the elements of these factors is that support from the central budget can be made on the basis of the Act on the initiative of the candidates. In other words according to the Act, the candidates can ask for/ 
use support from the central budget. This aid is therefore made for specific public law purposes, with a voluntary commitment, under certain statutory conditions, and with the risk of being repayable in the absence of a sufficient level of electoral support. The subsidized person (ie. the candidate) does not acquire a free disposable property right that can provide a free provision, but can use it only for the aim pursued, with close settlement (strict account). In this sense, therefore, the Constitutinal Court did not consider the financial support to be in a contitutional relationship with the right to property protected by the Basic Law.

Regarding the relationship between equal opportunities and funding, the $\mathrm{CC}$ indicated the following. Article XV para (4) of the Basic Law declares that the State shall promote the achievement of equality of opportunity. This requirement is implied in campaign finance regulation as follows: every candidate, regardless of the degree of electoral support that is shown in the candidacy, is eligible for equal budget support. Thus, the state ensures the neutrality (impartiality) of election campaign financing, and through this political pluralism in the elections. There is no appreciable constitutional relationship between Article XV. para (4) of the Basic Law and the challenged legal provision. Therefore the second judicial initiative was also rejected by the CC in Decision 3176/2015. (IX.23.) AB.

\section{CONSTITUTIONAL COURT DECISION NO. 3086/2016. (IV. 26.) AB - THE POSSIBILITY OF VOTING IN THE LETTER (BY MAIL)}

\subsection{The antecedent of the case}

The petitioner is a voter who has an address in Hungary ${ }^{18}$ but is abroad on the day of election. According to the Hungarian electoral law, he can only vote at the foreign representation. ${ }^{19}$ However, those who do not have an address in Hungary and are also abroad on the day of the election have the right to vote by mail. According to the petitioner this legal rule infringes the constitutional requirement of equality ${ }^{20}$ and his right to vote guaranteed by Article XXIII. of the Basic Law. ${ }^{21}$

${ }^{18}$ According to the law ,Address in Hungary' shall mean the address of a registered domicile in Hungary, or, in the case of persons with no registered domicile in Hungary or abroad, the address of a registered residence in Hungary.

${ }^{19}$ According to the law ,Foreign representation' shall mean the diplomatic and consular mission of Hungary operating abroad, set up based on a Government decision.

${ }^{20}$ Article XV para (1) Everyone shall be equal before the law. Every human being shall have legal capacity.

(2) Hungary shall guarantee the fundamental rights to everyone without any discrimination, in particular on grounds of race, colour, sex, disability, language, religion, political or other opinion, national or social origin, property, birth or any other status.

${ }^{21}$ Article XXIII para (1): Every adult Hungarian citizen shall have the right to vote and to stand as a candidate in elections of Members of Parliament, local government representatives and mayors, and of Members of the European Parliament. 
The case with the increased media coverage was dealt with by the $\mathrm{CC}$ six times in two and a half years. The latter figure is remarkably high and reflects the complex judgment of the case.

\subsection{The statements of the $\mathrm{CC}$ - homogeneous grouping}

The CC considered the question of voting by mail as a procedural, technical rule. Voters residing abroad on the voting day (whether or not they have an address in Hungary) are in a comparable situation and form a homogeneous group. ${ }^{22} \mathrm{Ho}-$ wever, the distinction between them does not concern the essential content of fundamental rights; voters with permanent residency abroad on the day of voting can exercise their right to vote; according to their choice, they may cast their votes at the Delegation or go home and vote in Hungary. Voter's right to vote as a constituent part of a voter who resides abroad on the day of the vote is complete and consequently does not affect or limit the difference in the procedural rule that is being challenged. This means - in other words - that voters residing abroad on election day thus have full access to their right to vote, so the claim made above is baseless.

The challenged regulation contains a different procedural (technical) rule for the members of the homogeneous group regarding the way (method) of voting, but an impartial analysis can identify a reasonable cause for this distinction. ${ }^{23}$

22 The CC examines the constitutionality of differentiation by applying a discrimination test. With respect to fundamental rights the necessity and proportionality test is used; in the case of non-fundamental rights the so-called reasonableness test is applied. In this latter case the first step of the examination by the $\mathrm{CC}$ is formation of a group. A homogeneous group of subjects needs to be set up who share certain characteristics that are relevant for the regulation concerned, because discrimination can only occur with respect to persons who are in comparable situations. There is discrimination either if different treatment is given to persons who belong to the same homogeneous group or if persons who belong to different homogeneous groups get identical treatment by disregarding significant differences. Márta Dezső, Bernadette Somody, Attila Vincze, Eszter Bodnár, Nóra Novoszádek, Beatrix Vissy: Constitutional Law in Hungary. Kluwer Law International. The Netherlands 2010. 262.

${ }^{23}$ According to the interpretation of the Hungarian CC the prohibition of differentiation is not absolute. It follows from the right to human dignity that everyone has to be treated as a person of equal dignity by law. Discrimination related to non-fundamental rights is unconstitutional if it violates the right to human dignity. If the differentiation is arbitrary or unjustified, that is to say, an impartial analysis cannot identify a reasonable cause, then it infringes the right to human dignity, because in that case it is certain that the persons concerned were not treated as persons of equal dignity and their points of view were not evaluated with the same attention and equity. Hence, it follows that with respect to a right that does not qualify as a fundamental right, discrimination is unconstitutional if it lacks a reasonable motivation. Márta Dezső, Bernadette Somody, Attila Vincze, Eszter Bodnár, Nóra Novoszádek, Beatrix Vissy: Constitutional Law in Hungary. Kluwer Law International. The Netherlands 2010. 262. 


\subsection{The statements of the $\mathrm{CC}$ - the intensity of the relationship with the state}

The CC considered that a distinction could be drawn between the members of the homogeneous group regarding the intensity of their relationship with the state. In the case of a voter with a permanent residence, the relationship is more direct, resulting from his or her habitual long-term residence in Hungary. The permanent residence regarding participation in public affairs also involves a more intensive relationship with the state, with its electoral system and the relevant legal regulations. This means - in other words - that those citizens who maintain permanent residences in Hungary are more likely to engage in public affairs, and thus to also have a more intensive relationship with the state.

Allowing voting by mail for voters who reside abroad but who do not have a permanent address on the day of the vote seems to be a procedural (technical) rule granting an advantage, promoting the exercise of a fundamental right. In the view of the $\mathrm{CC}$, it can not be considered solely on its own abstracted from the regulatory environment; this is accompanied by the restriction (lack of completeness) of the essential content of the fundamental right, with which voters with permanent address (as the members a homogeneous group, such as the complainant) does not have to count.

\subsection{The statements of the $\mathrm{CC}$ - signaling, message to the legislator}

It is relatively rare when the decision of the CC contains a message beyond the holdings. In the last paragraph of its decision, the CC pointed out that the legislator can change his discretionary decision, if he considers its technical and security conditions, and, if he considers it necessary, he can introduce legislation that would allow voting by mail for all voters residing abroad regardless of their place of residence. However, the possible modification of the procedural (technical) rule for voting discussed above is a discretionary decision of the legislator. From this "message" it may also be concluded that the generalization or even complete abolition of voting by mail may be in line with the Basic Law.

\subsection{Five dissenting opinions and seven concurring reasoning}

Egon Dienes-Oehm and András Zs. Varga in their concurring reasonings, pointed out that the distinction made between voters by law was not based on the method of voting (i.e. in letter or not) but on the existence or absence of a permanent residence in Hungary. This distinction is a procedural rule which, in itself, cannot conflict with Articles XV and XXIII of the Basic Law, since, in this case, 
it is only the determination of certain technical conditions for the exercise of the right to vote. Hungarian citizens with and without permanent addresses in Hungary cannot be considered a homogeneous group with respect to Article XV of the Basic Law. The distinction is based on reasonable and constitutional grounds set out in the Avowal of National Faith (preamble) of the Basic Law.

In László Salamon's concurring reasoning he pointed out that it is an essential theoretical question that the challenged regulation of the method of voting is not a restriction (constraint) on the right to vote but the establishment of the conditions for exercising the right to vote. The distinction between the two concepts is a constitutionally relevant distinction. In his concurring reasoning, Tamás Sulyok explicated the practice of the ECHR. István Balsai, Imre Juhász and Mária Szívós agreed with the holdings of the decisions, but they would have preferred to reject the petition without examining it on the merits. Ágnes Czine, Miklós Lévay, István Stumpf, Péter Szalay and Béla Pokol, in their dissenting opinions, stated that the $\mathrm{CC}$ would have had to declare an omission on the part of the lawmaker that results in violating the Basic Law. In this case, only a small majority of the members of the CC supported the majority decision. This fact is indicated by the five dissents and seven concurring reasoning, and by the fact that the Court discussed the case six times.

\section{3211/2016. (X. 26.) AB - HOLDING AN ELECTORAL MEETING}

\subsection{The antecedent of the case}

A Hungarian opposition political party submitted a constitutional complaint against the judgment of the Curia (Hungary's Supreme Court). According to the Curia, the event announced by the petitioner at 16:00 on October 2, 2016, at Kossuth tér (Budapest's main square at the Parliament), is considered as an electoral meeting on the basis of $\S 140$ (d) of the Act on Electoral Procedure. Therefore, the Curia concluded that the event violated the law, according to which an election meeting could not be held on the day of the vote, so the National Election Commission lawfully asked the petitioner to refrain from holding the event and forbade him from continuing to organize it.

\subsection{The statements of the $\mathrm{CC}$ - proportionality of the restriction on holding an electoral meeting}

According to the first two sentences of $\S 145$ (1) of the Act on Electoral Procedure, „Election rallies may be held during the campaign period. Election rallies shall not be held on the day of voting. Election rallies shall be public. The organiser of the rally shall arrange for the maintenance of order". Regarding this regulation, 
the petitioner challenged the restriction contained in the latter sentence. The CC established the following; the challenged provision is one of the cornerstones of the institutional protection of voting rights. Due to the short duration of the prohibition (i.e. 19 hours) the restriction is limited only to a small fraction of the duration of the campaign. The limitation of the freedom of peaceful assembly for a few hours therefore does not affect the essential content of the fundamental right.

The challenged provision temporarily restricted the freedom of peaceful assembly in order for the elections to be conducted smoothly and in order to achieve the will of the electors. The prohibition helps voters consider their opinions independently of new influences in the hours before the election. According to the reasoning of the petitioner, the electoral assemblies held on the day of voting have only a low influence of the voters. However, according to the CC, this is only an assumption, which is not capable of supporting the disproportionality of the restriction. It thus rejected the constitutional complaint in a five-member panel.

\section{CONSTITUTIONAL COURT DECISIONS NO. 19/2016. (X. 28.) AND 20/2016. (X. 28.) AB - POLITICAL ADVERTISEMENT OR ADVERTISEMENT FOR THE SOCIAL GOOD?}

\subsection{The antecedent of the case}

The basis of the process was the following: individuals submitted objections to a company providing linear media services (i.e. media service provider providing linear media services) because, in their view, the contested programs were classified as political advertisement and not as advertisements for the social good. Therefore, the individuals argued, these programs should not have been broadcast. The National Election Commission rejected the objections in both cases but the Curia found that broadcasting these programs infringed the electoral law regarding the publication of political advertising. In both cases, a business organization providing linear media services has submitted a constitutional complaint alleging that the decisions of the Curia infringe their right to media editing, guaranteed by Article IX of the Basic Law. ${ }^{24}$

\subsection{The statements of the $\mathrm{CC}$ - surplus obligations of the broadcaster}

In the reasoning of its decision, the $\mathrm{CC}$ pointed out that at the time of the referendum, no other content could be attributed to the concept of political adver-

\footnotetext{
${ }^{24}$ According to this article "Everyone shall have the right to freely express their opinion." (Article IX para 1)
} 
tising under the Constitution than the content should be attributed to during election-time. According to the CC's conclusion, the decision of the Curia is capable of restraining the broadcaster from broadcasting advertisement for the social good. In its interpretation, the Curia's judgment infringed the broadcaster's freedom to edit media content (i.e. its editorial independence), as protected by Article IX of the Basic Law.

\subsection{The statement of the $\mathrm{CC}$ - an important procedural issue}

During the proceeding the $\mathrm{CC}$ noticed insufficiency of legal rules regarding publication of decisions taken during the legal remedy procedure, thus the Court ordered constitutional review of $\S 232$ of the Act on Electoral Process. ${ }^{25}$ The legal basis of this review was $\S 28$ (1) of the Act on CC which declares that in proceedings aimed at the review of a judicial decision, the $\mathrm{CC}$ may also carry out the examination of the conformity of the legal regulation with the Basic Law.

As a result of this ex officio examination the $\mathrm{CC}$ declared an omission on the part of the law-maker that results in violating the Basic Law, because the lawmaker failed to enact such legal rules that would guarantee that the decisions of the second-instance electoral commission and the review court shall be communicated to all those, to whom these holdings of these decisions concern. Therefore, in its decision no 6/2017. (III.10) AB called upon the Parliament that committed the omission to perform its task for enacting such law.

\subsection{Dissenting opinions}

Ágnes Czine, Béla Pokol, István Stumpf, Tamás Sulyok and Péter Szalay made a dissenting opinion on the decisions because they disagreed with the annulment the Curia's judgments.

${ }^{25} \S 232$ of the Act of Electoral Process reads: (1) The resolution adopted in the appellate procedure shall be communicated by the election commission that proceeded in the second instance to the appellant and those to whom the resolution of the first instance had been communicated.

(2) The election commission, when acting in a procedure of second instance and after its resolution became final, shall send back the documents sent to aid in adjudicating the appeal, along with the resolution, to the election commission that proceeded in the first instance.

(3) The decision adopted in the course of the judicial review shall be communicated by the court to the submitter of the request and those to whom the resolution of second instance had been communicated.

(4) Except for personal data, the court shall publish its decision.

(5) No further legal remedy shall be available with regard to court decisions.

(6) The court shall send back to the election commission that issued the reviewed resolution the documents sent to aid in adjudicating the request for judicial review - together with the court's decision - after the passing of the deadline available for constitutional complaints or in case a constitutional complaint has been filed, after it has been returned from the CC. 


\section{CONCLUSIONS}

In this paper, we introduced and analyzed those Hungarian Constitutional Court cases that examined the legislation on the electoral system and were decided after the entry into force of the new Constitution of Hungary (called the Basic of Fundamental Law) in 2012. Based on this analysis, it can be observed primarily that between 2012 and 2017 the Constitutional Court examined the constitutionality electoral norms of Hungary in eight significant decisions on the merit. When making these decisions, the Constitutional Court repeatedly returned to its decisions based on the previous Constitution, to its caselaw of the two decades preceding the Fundamental Law, despite the fact that the Court itself recognized the textual changes of the provisions of the former Constitution and the Fundamental Law on the electoral law. Among the most important principles developed by the former Constitutional Court case, the most significant was that „The Parliament has a wide scale of discretion in establishing the system of election and the rules of procedure for the election. The legislature is free to define the constituency systems and the rules pertaining to the nomination of candidates, voting and the obtainment of mandates. The Parliament may exercise this freedom of discretion in establishing the rules of election only within the constitutional limits, and it is required to adopt rules that do not violate the provisions of the Constitution and do not unconstitutionally restrict any fundamental right regulated in the Constitution." This basic principle was established previously in 1996 and became a consistent practice of the Constitutional Court and this statement was confirmed even after the entry into force of the Fundamental Law (for the first time in Decision $1 / 2013$. AB.)

From the analyzed decisions it can also be concluded that the Constitutional Court, in accordance with its previous practice, made its decisions in accordance with the constitutional provisions, taking into account the international standards, such as the Venice Commission's Code of Good Practice in Electoral Matters and the European Court of Human Rights' caselaw.

It is also apparent from the analyzed judgments that relatively few unanimous decisions have been made, in many cases dissenting opinions and concurring reasonings were attached by some justices to the majority decision. Furthermore, we could find such decision, where the number of justices attaching dissenting opinions and concurring reasonings exceeded the number of the justices adopting the majority decision. This phenomenon clearly indicates the division of thought within the Constitutional Court, and this might also bring some changes and reconsideration of the majority's opinion in the future. 
Др Андращи Тег̄лащии, ванредни иррофесор

Национални универзииеей за државну службу, Будимиеешйа

Факулиетеи за иравне науке и државну уираву

Teglasi.Andras@uni-nke.hu

\section{Пракса Уставног суда у области уставности парламентарног изборног система Мађарске у периоду од 2012. до 2017. године}

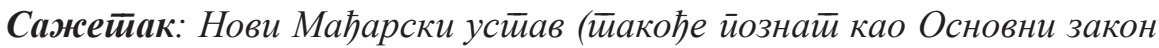
или Фундаментиални закон) изменио је ирравила која се односе на избор ила-

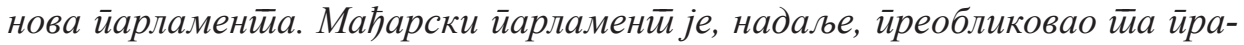
вила накнадним донощењем два законска актиа: Акйа ССIII од 2011. гоодине

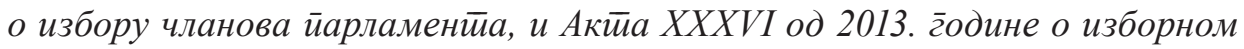

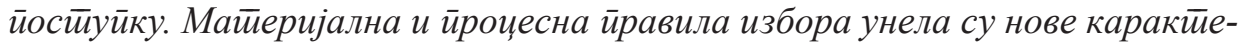
ристиике у изборни систием које су мног̄и критииковали из устиавних разлог̄а. Рад на систиемайски начин ириказује одлуке Усйавног суда Мађарске о иравним нормама које регуулищу йарламенйарне изборе како су се развијале

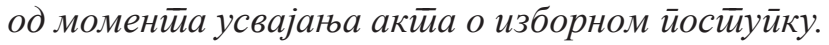

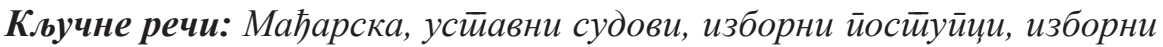
системем.

Датум пријема рада: 24.05.2018. 

ОДЕЉАК ЗА СТУДЕНТЕ 
